\title{
Government Budget Deficit and \\ Economic Growth: Evidence from Iraq 1980-2018
}

\author{
Prof. Saud Ghali Sabr \\ saud.sabr@univsul.edu.iq
}

\author{
Dr. Younis A. Ahmed \\ uns.ahmad@univsul.edu.iq \\ Department of Economics \\ College of Administration and Economics \\ University of Sulaimani, Iraq
}

\author{
Twana N. Mohamad Khan \\ twana.najaf@sulicihan.edu.krd
}

\begin{abstract}
In the recent economic literature, there has been a great deal of discussion about the impact of budget deficits on economic growth in both developed and developing countries. Many economists and other observers have viewed the budget deficits as harmful to the world economies. The supposed harmful impacts include high real interest rates, low savings and low rates of economic growth. This paper examines the real impact of budget deficits on economic growth in Iraq in the short and long term. A time series analysis has been used as a sample in view of the period between 1980 and 2018. The Autoregressive Distributed Lag (ARDL) model has been used for the regression analysis. The results show a weak positive impact from budget deficit on economic growth in the short term, but a strong negative impact from the accumulating budget deficit on economic growth in the long term.
\end{abstract}

Keywords: Budget Deficit, Economic Growth, ARDL Model, Iraqi Economy.

\section{Introduction}

A common problem that has faced developed and developing countries are the notion of a budget deficit. The existence of different types of budget deficits (that is active, passive, structural and cyclical) and their impact on the economy has been the topic of debate among economic and political scholars for several decades (Rocha, 1995). There are complex factors leading to why this issue occurs, including the fact that government expenditure can exceed government revenue and the 2008 financial and economic crisis.

If a budget deficit has gradually increased, most governments aim to increase and diversify the source of revenue or reduce the total expenditure. These phenomena could lead to further problems, such as increasing the debt burden and a depletion of financial reserves.

Since the 1970s, one of the most important macroeconomic issues discussed in academic and political spheres is the existence of a budget deficit (Barişik and Baris, 2017). In certain countries especially developing countries, this issue has incrementally increased. Therefore, it has an effect on a government's economic policy in their struggle against macroeconomic problems, which include unemployment, inflation, foreign debt, high inflation and difficulties with payment balances, exchange parallel markets and other various external shocks.

In the twenty first century, governments, especially those in developed countries, have a budget deficit problem because they spend a significant amount of their budget on healthcare and social welfare programmes (Tanzi and Schuknecht, 1997).In contrast, in developing countries, budget deficits occur for differ-

* This article was submitted in January 2019, accepted for publishing in March 2019 and published on March 2021.

(c) Arab Administrative Development Organization- League of Arab States, 2021, pp 345-368،

DOI: 10.21608/aja.2021.151252 
ent reasons, such as the ISIS war (as in Iraq in the 2014), a fluctuation in oil prices in oil exporting countries (mostly in Arab countries), natural disasters (such as in ASEAN countries), political issues (in the case of Iran) and economic crises.

There are various claims about the positive and negative impact of a budget deficit, and this issue has taken a prominent place in many programmes of economic reform. It seems that the relationship between a budget deficit and certain macroeconomic variables, such as economic growth, is still the main focus of discussion theoretically and empirically. Until now, in the literature there is no clear view that have been developed to investigate the relationship between a budget deficit and economic growth. (Arjomand, Emami et al. 2016) used panel model analysing to estimate the impact of budget deficit on economic growth. in the first model in which government budget deficit is the dependent variable, the result have demonstrated that there is a positive relationship between a governmental budget deficit and economic growth in Middle Eastern and North African (MENA) countries. On the other hand, the results from the second model, where a budget deficit is an independent variable; the same study maintained that there is a negative correlation between a budget deficit and economic growth in these MENA countries.

In view of the Iraqi budget, it has also suffered budget deficit. This problem began during the 1980 s, when government expenditure significantly increased, and source of revenue remains the same until now. The budget deficit can be addressed through policy, and Iraq needs to take into account the views of the International Monetary Fund (IMF), without being applied literally and subject to criticism and scrutiny to overcome negative social influences.

The main objective of this study is to investigate the relationship between a government budget deficit and economic growth in Iraq. Recently, many studies have looked at the impact of certain variables, such as inflation (Sargent and Wallace, 1981), exchange rates (Gülcan and Bilman, 2005), private investment decisions(Yellen 1989) and economic productivity (Antwi and Atta Mills, 2013), on economic growth. This study aims to bridge this empirical gap by providing the impact of a government budget deficit on economic growth from Iraq as one of the Western Asian developing countries.

The paper is structured into six sections. Section two provides three theoretical views about the relationship between a budget deficit and the gross domestic product (GDP). Section three includes relevant experimental research literature that has used different variables and models. Section four presents the Iraqi budget distribution, public revenues, public expenditure and the budget deficit. The methodology employed, the model specifications, the methods of data collection, the model (tests) and the discussion of results are provided in Section five. The last section concludes the conclusion of the study, policy implementation, recommendation and some suggestion for further researchers.

\section{Theoretical Framework}

In terms of the theoretical framework, understanding the relationship between a government budget deficit and its economic growth has been divided into three main schools of thought: Keynesian, Neoclassical and Ricardian theories (Bernheim, 1989). A description of each school of thought's views about the relationship between a government's budget deficit and economic growth is discussed in this section.

Keynesian theory suggests that a budget deficit will have a positive influence on an economy's real growth rate (Coddington, 1976). At times, a government might have a reason to induce a deficit as part of a particular strategy, such as dealing with wartime situation and the ensuing economic crisis (Shaviro, 1997). This school of economic theory focuses on the notion of "expansionary" or the "crowding in" effect of a budget deficit on the economy on account of certain increases in domestic production and private investment (Modigliani, 1995). 
On the other hand, Keynesian theory does not consider a budget deficit to be a problem, if exceeding government expenditure is going to the right place (investment). As such, (Eisner, 1989) claimed that a government budget deficit can lead to an increase in aggregate demand and improve savings and private investment. Furthermore, if the government budget deficit comes from an increased expenditure on public infrastructure (Aschauer, 1989), social welfare or education, it leads to improved future economic activity (Herrera, 2007).Then, the variable coefficient expounds that financial policies must be used in a way that leads to the growth of production in economics (Alesina, Roubini et al., 1997).

Neoclassical theory argues that crowding-in has an effect only in the short term (Elmendorf and Mankiw, 1999). The Neoclassical school of thought believes that individuals plan their expenditure over their entire levies. By shifting taxes to future generations, budget deficits increase current consumption. By assuming full employment of resources, the Neoclassical theory argues that increased consumption implies a decrease in savings. Interest rates must rise to bring equilibrium to the capital markets. Higher interest rates, in turn, result in a decline in private investment. Thereafter, by adopting a budget deficit, governments transfer the tax burden to the future (Bernheim, 1989). Neoclassical economists believe in the crowding-out effect of budget deficits. This refers to the negative impact as in the "financial crowding-out" effect of a budget deficit, which means that the government is not able to influence economic activities with any fiscal measures (Buiter, 1977).

There are two distinct mechanisms by which the crowding-out effect occurs. In a closed economy, a switch from current taxation to a budget deficit raises real interest rates and crowds out investment. In contrast, in small, open economies, with internationally mobile capital, net exports, rather than domestic investment, are crowded out. Deficits place an upward pressure on interest rates, inducing an inflow of foreign funds. With flexible exchange rates, an influx of capital causes the country's currency to appreciate, which diminishes the competitiveness of its products in the world markets. In a large, open economy, such as the United States (US), both crowding in and crowding out mechanisms are likely to be operative (Yellen, 1989). As a result, a crowding-out scenario may lead more rapidly to a crisis characterised by a sharply declining output and consumption (Tobin, 1986). Basically, the crowding-in effects only exist in the short term because tax burdens are shifted to the future. Increasing current private consumption and decreases in personal savings are the causes of a budget deficit in this instance.

Ricardian theory was introduced by David Ricardo and completed by (Barro, 1989). This theory focuses on two assumptions, which include a household perspective and a household's vision until taxation. He suggests that a government's budget deficit leads to an increase in private savings, more than would be achieved through tax cuts so that the desired national savings decline. Therefore, a country's decision to substitute a budget deficit for current taxation leads mainly to increased borrowing from abroad, rather than to a higher real interest rate. The other choice is increasing government bonds as a result of decreasing taxes, which offers a temporary income for an individual at the present time. Accordingly, the government increases their savings and debts; also, the consumer increases their savings and provides higher tax payments in the future.

Budget deficits lead to another deficit, which is a current account deficit. Expected real interest rates rise for a particular country only if it is sufficiently large to influence the world markets, or if the increased national debt induces foreign lenders to demand higher expected returns on this country's obligations.

By contrast, there is a weaker tendency for a country's budget deficit to crowd out its domestic investment in the short term and its stock of capital in the long term. However, the current account deficits show up in the long term as a lower stock of national wealth and correspondingly higher claims by foreign investor. In short, Ricardian theory suggests that a budget deficit is a necessary cost of the government, 
which must be paid now or in the future. Therefore, the policy of tax cuts does not influence consumption or savings; also, it does not affect economic growth.

All in all, these schools of thoughts can be summarised in the following diagram:

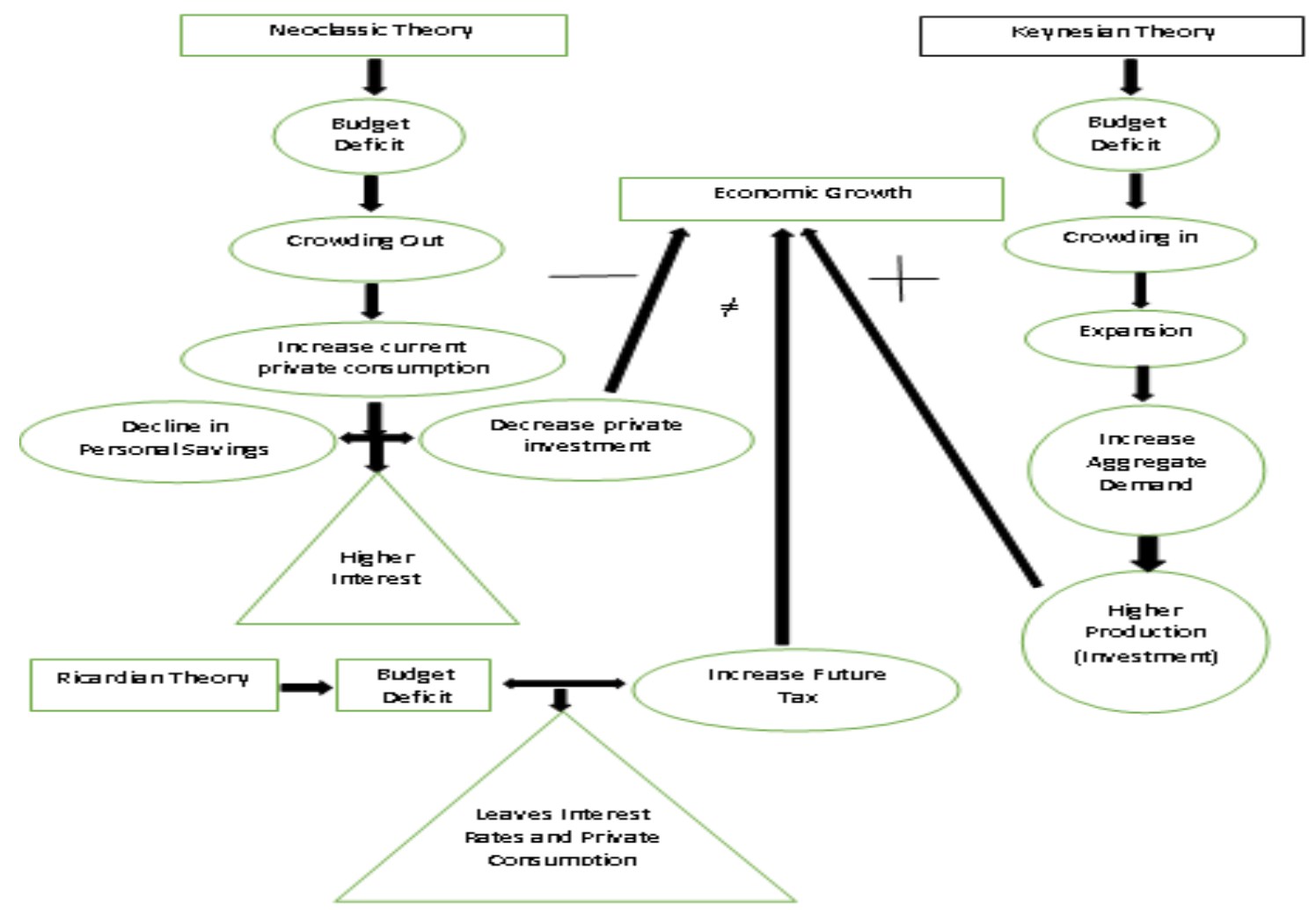

Figure 1: Theoretical framework of a budget deficit and economic growth

Further to this, the question is which of these theories is most relevant to the Iraqi economy? Can the Iraqi budget deficit lead to economic growth? Can the Iraqi government use their deficit to improve the economic infrastructure? Could the Central Bank of Iraq reverse the budget deficit? How can the Iraqi government balance their total revenue and total expenditure?

\section{Empirical Literature Review}

There have been several empirical studies on developed and developing countries, which examine the relationship between budget deficits and economic growth, but there has been little consensus about the existence of the relationship between these variables.

The diverse impact of budget deficit on economic growth has been found by Saleh and Harvie (2005). Their study used different models, such as IS-LM, simultaneous equations and a simple equation model to test the relationship between different economic variables. It further analyses the impact of a budget deficit on macroeconomic variables, such as growth, interest rates, trade deficits and exchange rates.

(Landau 1983) tested the relationship between government consumption expenditure in GDP and the rate of growth. The results show that there is a negative relationship between government's consumption expenditure in GDP and the rate of growth of per capita GDP. (Guess and Koford, 1986) used the Granger causality test in seventeen of the Organisation for Economic Co-operation and Development (OECD) countries for the period between 1949 and 1981. In their study, it was found that a budget deficit does not cause a change in inflation, GDP or private investment; rather, there is weak evidence that inflation and a recession cause a deficit. As a result, they claimed that deficits are a symptom, rather than a cause of inflation and a reduced national output. 
By contrast, a study by (Argimon, Gonzalez-Paramo et al., 1997) examined the relationship between government expenditure and private investment, and the impact of government consumption on private investment productivity in 14 OECD countries by applying penal data. Their results demonstrated that government consumption appears to crowd out private investment, and that deficit reductions engineered through cuts in public investment could severely impinge on private capital accumulation and growth prospects.

In a study conducted by (Tanzi, 1985) the relationship between the fiscal deficit and interest rates used data between the years of 1960 and 1984 in the US. It claimed that interest rates are positively influenced by fiscal deficits. Moreover, it indicated that if the US fiscal deficit had been lower effect, interest rates would have been even lower (Cohen and Garnier, 1991; Elmendorf, 1993; Elmendorf, 1996; Evans, 1987; Feldstein,1986; Wachtel and Young, 1987). Furthermore, (Elmendorf, 1996) found minimal relationship between a budget deficit and real interest rates. From their study suggested that the law is consistent with the predictions of economic theory. His study concluded that higher expected government expenditure and budget deficits raised real interest rates and the value of the dollar while lower expected spending and deficits reduced real rates and the value of the dollar.

(Al-Khedair, 1997) used the Vector Autoregressive (VAR) model by selecting data from the G7 countries for the period from 1964 to 1993. It found that there is a positive and significant impact of a budget deficit on economic growth. By contrast, (Huynh, 2007)examined Asian countries for the period between 1990 and 2006, and claimed that there is negative impact of a budget deficit on economic growth.

Finally, it has been observed that different results were obtained based on the development level of the country and the econometric methods used. The table below includes some of the studies involved in observing the relationship between a budget deficit and economic growth.

\section{Table 1: Empirical studies related to economic growth and a budget deficit}

\begin{tabular}{|c|c|c|c|c|}
\hline Authors & $\begin{array}{c}\text { Publication } \\
\text { Year }\end{array}$ & Method & Countries & $\begin{array}{c}\text { Result/ Relationship } \\
\text { between (BD and GDP) }\end{array}$ \\
\hline $\begin{array}{c}\text { (Yunana Titus Wuyah \&Amba } \\
\text { Daniel Amwe) }\end{array}$ & 2015 & Vector auto-regression & Nigeria & Negative \\
\hline (Edame \& Okoi) & 2015 & Chow endogenous break test & $\begin{array}{c}\text { Nigeria/ } \\
\text { democratic regime }\end{array}$ & Negative \\
\hline (Awe \& Funlayo) & 2014 & OLS regression & Nigeria & Negative \\
\hline (Fatima, Ahmed, \& Rehman) & 2012 & OLS regression & Pakistan & Negative \\
\hline (Jalles) & 2011 & Threshold & 155 countries & Negative \\
\hline (Guess \& Koford) & 1984 & Simple regression & 100 countries & Negative \\
\hline (Arjomand, et al.) & 2015 & Generalised Least Squares (GLS) & MENA countries & Positive \\
\hline (Edame and, et al.) & 2015 & Chow endogenous break test & $\begin{array}{c}\text { Nigeria/ } \\
\text { military regime }\end{array}$ & Positive \\
\hline (Dao) & 2014 & Vector error correction & Pakistan & Positive \\
\hline (Bahmani-Oskooee) & 1999 & Johansen-Juselius Cointegration & United States & Positive \\
\hline $\begin{array}{c}\text { (Argimón, González-Páramo, } \\
\text { \& Roldán) }\end{array}$ & 1997 & Fix and Random effect & 14 OECD countries & Positive \\
\hline (Ghali) & 1997 & Vector autoregressive (VAR) & Saudi Arabia & Not impact \\
\hline (Guess \& Koford) & 1984 & Granger causality & 17 OECD countries & Not impact \\
\hline
\end{tabular}

To sum up, there are a few studies in the literature that focus on the impact of a budget deficit on economic growth in the Iraqi economy (Salm, 2012). Hence, there are different results in the literature about the correlation between a government budget deficit and economic growth. Thus, the current study aims to fill this gap and determine the relationship between these two variables in the short and long term in Iraq by using the Autoregressive Distributed Lag (ARDL) model. 


\section{Iraqi Budget Distribution and Deficit}

Iraq has huge natural resources in oil and gas. According to the Oil Gas Journal, Iraq held 144 billion barrels of crude oil reserves in 2015, representing almost $18 \%$ of its proven reserves in the Middle East and around $9 \%$ of the global reserves, meaning that it ranked fifth in the world (Worldwide, 2015). The Iraqi budget is different from other countries in terms of its sources of revenue and channels of expenditure. Moreover, most of the government revenue comes from oil exports, which in 2003 was 89.13\%, and in 2018 , it was approximately $84.19 \%$. On the expenditure side, most of it goes to the operating expenditure, which accounted for $79.74 \%$ in 2003 , and in 2018 , it decreased to $52.96 \%$.

In addition, the government's operational expenditure is much higher than its investment expenditure; for example, between 2003 and 2018, the government operating expenditure was between 52.9\% and $79.9 \%$. While its investment expenditure was around $20.3 \%$ and $47.1 \%$. Figure 2 shows the percentage of operational expenditure and investment expenditure (in capital projects) from 2003 to 2018.

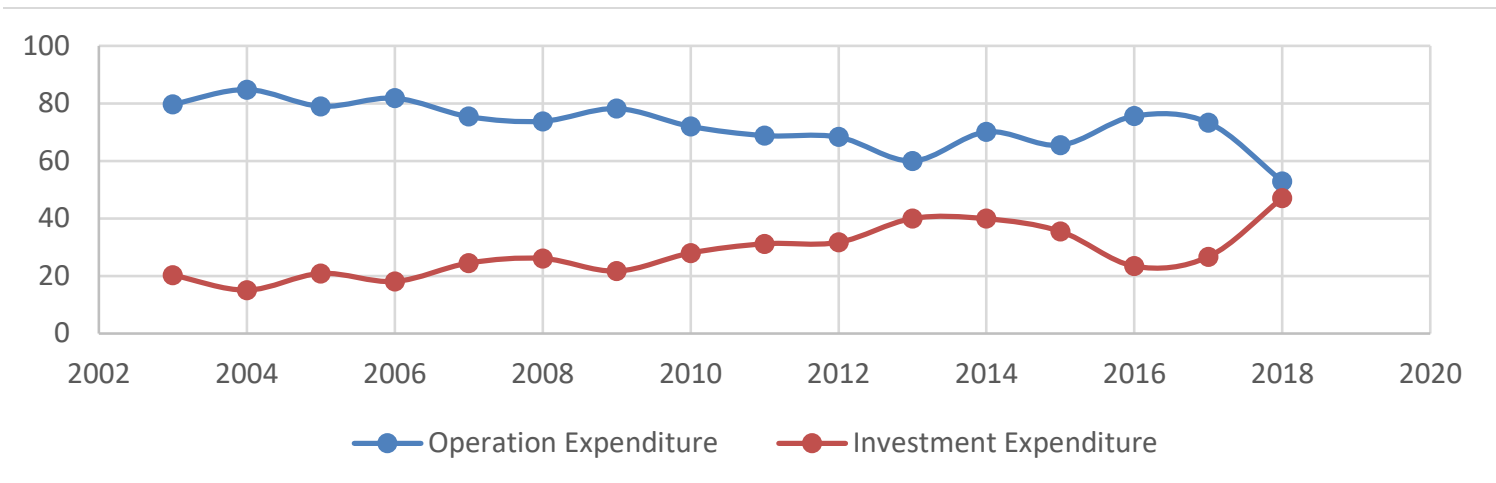

Source: Republic of Iraq, Ministry of Finance and Ministry of Planning.

Figure 2: Iraqi government expenditure distribution 2003-2018

One of the reasons for the Iraqi government operational expenditure is due to the huge number of public employees, which is around 5 million, and also certain defects in their distribution policy. In 2003, after Iraq was invaded by the US and the ensuing establishment of a new government, their expenditure fluctuated. The highest point of the expenditure growth rate was in 2003, at $264 \%$. After that point, it started to decline reaching its lowest level in 2014at $-39.6 \%$. This was on account of fighting ISIS and declining oil prices. By 2018, it reached $-2.3 \%$.

On the other hand, there is an imbalance in the sources of revenue in the Iraqi budget. In 2013, the highest point of government revenue, at $97.5 \%$, was derived from oil revenues. Figure 3 shows the oil and nonoil revenue of Iraq's total revenue from 2003 to $2018^{(1)}$.

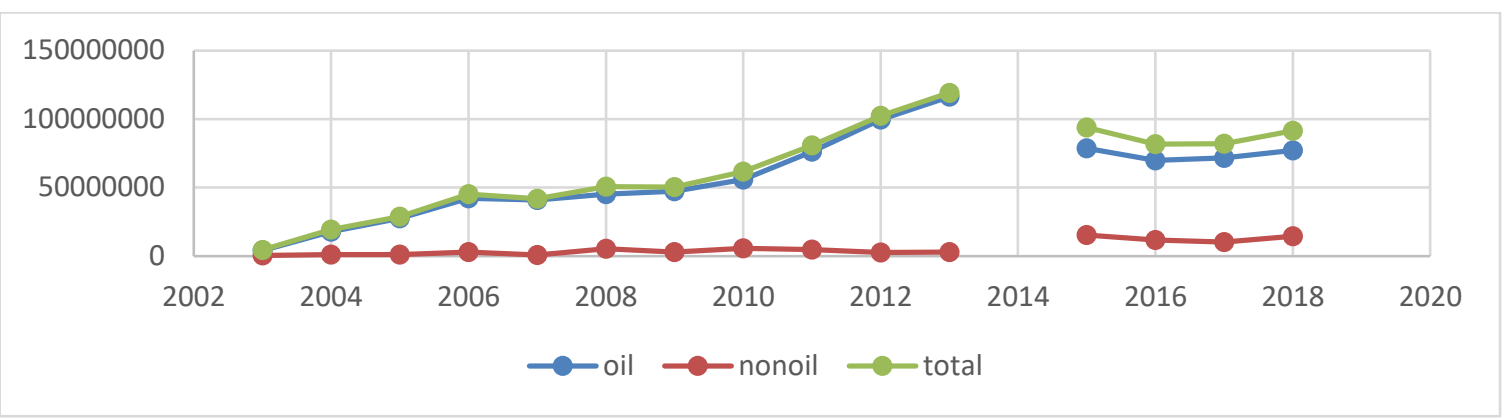

Source: Ministry of Finance and Ministry of Planning

Figure 3: Percentage of government revenue 2003-2018

(1) Nonoil revenue includes customs duty, income tax, returns from state-owned entities, user fees and charges, other taxes and income. 


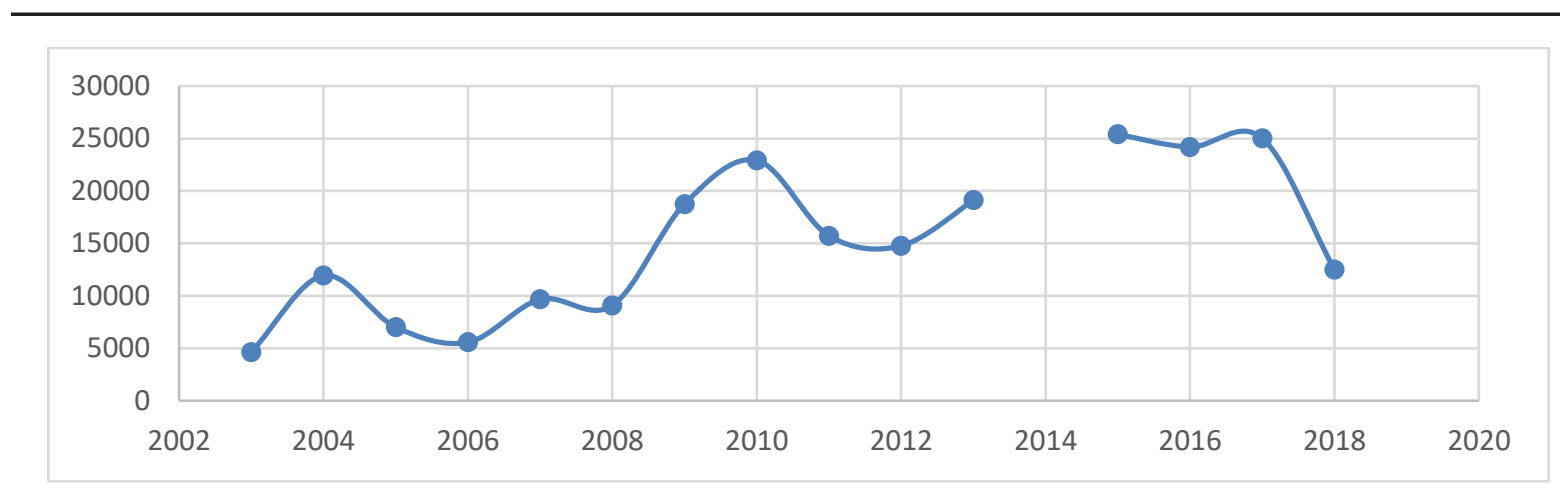

Source: Republic of Iraq, Ministry of Finance and Ministry of Planning 2018.

Figure 4: Amount of budget deficit in Iraq 2003-2018

Therefore, these imbalances and fluctuations in both government expenditure and revenue created a problem for the Iraqi government, which was the budget deficit. If the graphs above are compared, it is possible to conclude that generally a budget deficit is increased by raising the operational expenditure, and it is decreased by reducing the operational expenditure. Figure 4 shows the what the percentage of the budget deficit of the GDP was (22.5 to 4.9) from 2003 to $2018^{(1)}$.

Moreover, the government budget deficit, percentage of total government expenditure, total revenue and GDP is described in the table (2).

The table (2) shows that there is a deficit in the Iraqi budget during the period between 2003 and 2018. The highest percentage of the budget deficit in the GDP was in 2003, at $22.5 \%$, which decreased to $5.78 \%$ in 2008 . Thereafter, it fluctuated until 2018, with the subsequent highest amount recorded in 2015, at $12.72 \%$. One of the reasons for these incremental increases in the budget deficit in the Iraqi budget is the continuous form of government expenditure compared to the government's total revenue.

Table2: Budget deficit and its proportion to expenditure, revenue, and GDP in Iraq 2003-2018

\begin{tabular}{ccccc}
\hline $\begin{array}{c}\text { Time } \\
\text { period }\end{array}$ & $\begin{array}{c}\text { Tudget } \\
\text { deficit }\end{array}$ & $\begin{array}{c}\text { of bercentage } \\
\text { of the (total } \\
\text { expenditure) }\end{array}$ & $\begin{array}{c}\text { The percentage } \\
\text { of budget } \\
\text { deficit of the } \\
\text { total revenue) }\end{array}$ & $\begin{array}{c}\text { Thercentage } \\
\text { of budget defi- } \\
\text { cit of the } \\
\text { GDP }\end{array}$ \\
\hline 2003 & 4636.2 & 50.22424 & 100.8747 & 22.54742 \\
\hline 2004 & 11935.2 & 35.45706 & 54.92752 & 22.41984 \\
\hline 2005 & 7022.5 & 19.51725 & 24.2498 & 9.550134 \\
\hline 2006 & 5570.9 & 10.93126 & 12.27233 & 5.828094 \\
\hline 2007 & 9662.9 & 18.68021 & 21.44214 & 8.669777 \\
\hline 2008 & 9086.8 & 15.17958 & 15.73472 & 5.786812 \\
\hline 2009 & 18757.3 & 27.11925 & 37.21022 & 14.35768 \\
\hline 2010 & 22922.1 & 27.07644 & 37.12983 & 14.14386 \\
\hline 2011 & 15727.9 & 16.27086 & 19.43275 & 7.236975 \\
\hline 2012 & 14768 & 12.62222 & 14.43315 & 5.809027 \\
\hline 2013 & 19127 & 13.81769 & 16.03323 & 8.050525 \\
\hline 2014 & - & & & - \\
\hline 2015 & 25414 & 21.27371 & 27.02237 & 12.72513 \\
\hline 2016 & 24194 & 22.84716 & 29.61322 & 11.86742 \\
\hline 2017 & 25019 & 23.36281 & 30.48532 & 11.0706 \\
\hline 2018 & 12514 & 12.01455 & 13.65516 & 5.693176 \\
\hline Note: In 2014, there is missing data because of the war with ISIS. \\
\hline $\begin{array}{l}\text { Source: The researcher based on data from the Ministry of Finance } 2018 \text { http://www. } \\
\text { mof.gov.iq/pages/ar/federalbudgetlaw.aspx }\end{array}$
\end{tabular}

\section{Research Methods and Model Specification}

To investigate the impact of a budget deficit on economic growth, several models have been used. The research methods employed in this paper are the co-integration distribution ARDL model and the time series econometrics to estimate the short- and long-term impact of the government's budget deficit on Iraqi's economic growth from 1980 to 2018. The data type was secondary data collected from the World Development Indicator (WDI), Central Bank of Iraq (CBI), Ministry of Finance, Ministry of Planning and Previous research (Fatima et al., 2012). The model specification used in this paper was developed by (Shojai, 1999) to assess the impact of a budget deficit on economic growth (the GDP). Moreover, the same model has used by (Fatima et al., 2012) and Van and Sudhipongpracha (2015). The econometrics expression of the model is as follows: 


$$
L n G D P_{t}=B_{o}+B_{1} L n I N F_{t}+B_{2} \operatorname{LnEXCH}_{t}+B_{3} \operatorname{LnRIR}_{t}+B_{4} \operatorname{LnBD_{t}}+B_{5} \operatorname{LnGI}_{t}+e_{t} \cdots
$$

In this step, the current study has used this model to examine the impact of the Iraqi budget deficit on economic growth for the period between 1980 and 2018. This study replaced two important variables (the export and exchange rates) in the model. The reason for replacing these variables in the model is due to the efficiency of these variables on the Iraqi government's economic policy. Most of the total government revenue (85\%) comes from oil, which is exported abroad. For the expenditure part, around $60 \%$ of the government's expenditure is operational expenditure. The low performance of the manufacturers and the low levels of local production make the Iraqi market completely dependent on the foreign imported goods, which is why the exchange rate was used as an independent variable. Any fluctuations in the Iraqi currency affect the price of foreign goods and services in the market. As a result, the model that has been used to test the impact of the Iraqi budget deficit on economic growth is:

$$
L G D P_{t}=B_{o}+B_{1} L B D_{t}+B_{2} L E X C H_{t}+B_{3} L E X_{t}+B_{4} L O E_{t}+e_{t} \ldots \ldots
$$

where

$$
\begin{aligned}
& \text { - } \quad \mathrm{GDP}=\text { Gross Domestic Product } \quad \text { - } \mathrm{BD}=\text { Budget Deficit } \\
& \text { - } \quad E X=\text { Export } \\
& \text { - } \quad \mathrm{e}=(\text { Error Term }) \\
& \text { - } \mathrm{OE}=\text { Government Operation Expenditure } \\
& \text { - L = Logarithm }
\end{aligned}
$$

\section{Unit Root Test (Augmented Dickey-Fuller Test)}

A time series analysis method was used in the study to investigate whether a variable was stationary or not. When no stationary series are used in the regression analysis, it is said to be spurious (Lim, n.d.). If this problem exists, the results might not be reliable. The non-stationary data should be made stationary before using them in a regression analysis in order to obtain reliable results.

A type of stochastic process that has received a great deal of attention and scrutiny by the time series analysts is the so-called stationary stochastic process. Broadly speaking, a stochastic process is said to be stationary if its mean and variance are constant over time, and the value of the covariance between the two time periods depends only on the distance, gap or lag between the two time periods, and not on the actual time at which the covariance is computed(Gujarati, 2004).

The popular method that has used by researchers to test the hypothesis as to whether the variables have the unit root or not is the model created by the two statisticians Dickey and Fuller (1981). The Augmented Dickey-Fuller (ADF) test is conducted by "augmenting" the preceding three equations by adding the lagged values of the dependent variable $\Delta \mathrm{Y}_{\mathrm{t}}$. The ADF test here consists of estimating the following regression:

$$
\Delta Y_{t}=B_{1}+B_{2} t+\delta Y_{t-1}+\sum_{i-1}^{m} a_{i} \Delta Y_{t-i}+\varepsilon_{t}
$$

Where $\varepsilon$ is a pure white noise error term and $\Delta \mathrm{Y}_{\mathrm{t}-1}=\left(\mathrm{Y}_{\mathrm{t}-1}-\mathrm{Y}_{\mathrm{t}-2}\right), \Delta \mathrm{Y}_{\mathrm{t}-2}=\left(\mathrm{Y}_{\mathrm{t}-2}-\mathrm{Y}_{\mathrm{t}-3}\right)$. The number of lagged difference terms to include is often determined empirically, the idea being to include enough terms so that the error term is serially uncorrelated. The table (3) illustrates the unit root test results.

The ADF t-statistic of the LGDP at the level form with the constant is equal to (-0.16), which is greater than the constant critical values at both the $1 \%(-3.62)$ and $5 \%(-2.94)$ significance levels, and the probability is more than $5 \%$, which is (0.9340). In addition, the value of the ADF t-statistics at the level form of the value with the constant and trend of the LGDP is equal to (-3.60), which is also greater than both the $1 \%$ $(-4.22)$ and $5 \%(-3.63)$ significance levels.

All previous results show that the LGDP is non-stationary at the level form, and thus there was a failure in rejecting the null hypothesis. Otherwise, by taking the first difference for this variable, the value of the ADF t-statistic became (-8.51) at the constant, and its value is (-8.51) at the constant and trend. In both 
cases, these ADF values are lower than the critical value with the constant $1 \%(-3.62)$ and $5 \%(-2.94)$ significance levels, and with the constant and trend of $1 \%(-4.23)$ and $5 \%(-3.54)$ significance levels, and the probability (0.00), respectively.

Thus, these results show that the LGDP is stationary, and the null hypothesis can be rejected. Similarly, the ADF t-statistic value of the series LBD, LECH and LEX have unit root problems at the level form, but their values are stationary after taking the first difference for them. It means that all the variables are I (1), not I (0). Thus, this result supports a co-integration analysis between these variables, and in this study the Johansen co-integration test is used.

\section{Table 3: Unit root test results}

\begin{tabular}{|c|c|c|c|c|c|c|c|c|c|}
\hline \multirow{3}{*}{ Variable } & \multirow{3}{*}{$\begin{array}{l}\text { Level and first } \\
\text { difference }\end{array}$} & \multicolumn{7}{|c|}{ Augmented Dickey-Fuller (ADF) statistics test } & \multirow[b]{3}{*}{ Prob.* } \\
\hline & & \multirow{2}{*}{$\begin{array}{c}\text { ADF } \\
\text { t-statistic }\end{array}$} & \multicolumn{2}{|c|}{$\begin{array}{l}\text { Critical value with } \\
\text { the constant }\end{array}$} & \multirow[b]{2}{*}{ Prob.* } & \multirow{2}{*}{$\begin{array}{c}\text { ADF } \\
\text { t-statistic }\end{array}$} & \multicolumn{2}{|c|}{$\begin{array}{l}\text { Critical value with the } \\
\text { constant and trend }\end{array}$} & \\
\hline & & & $1 \%$ & $5 \%$ & & & $1 \%$ & $5 \%$ & \\
\hline \multirow[t]{2}{*}{ LGDP } & Level & -0.1654 & -3.6267 & -2.9458 & 0.9340 & -3.6033 & -4.2268 & -3.6366 & 0.1432 \\
\hline & 1st Difference & -8.5152 & -3.6267 & -2.9458 & 0.0000 & -8.5183 & -4.2349 & -3.5403 & 0.0000 \\
\hline \multirow[t]{2}{*}{ LBD } & Level & -1.7561 & -3.6267 & -2.9458 & 0.3955 & -1.5822 & -4.2349 & -3.5403 & 0.7803 \\
\hline & 1st Difference & -5.7776 & -3.6394 & -2.9511 & 0.0000 & -5.8025 & -4.2528 & -3.5484 & 0.0002 \\
\hline \multirow[t]{2}{*}{$\mathrm{LXCH}$} & Level & -1.4874 & -3.6463 & -2.9540 & 0.5274 & -1.4789 & -4.2627 & -3.5529 & 0.8166 \\
\hline & 1st Difference & -5.4764 & -3.6537 & -2.9571 & 0.0001 & -5.4395 & -4.2732 & -3.5577 & 0.0005 \\
\hline \multirow[t]{2}{*}{ LEX } & Level & -2.3352 & -3.6267 & -2.9458 & 0.1669 & -2.8193 & -4.2627 & -3.5529 & 0.2008 \\
\hline & 1st Difference & -4.9217 & -3.6267 & -2.9458 & 0.0003 & -4.8777 & -4.2349 & -3.5403 & 0.0019 \\
\hline \multirow[t]{2}{*}{$\mathrm{LOE}$} & Level & -1.0060 & -3.6210 & -2.9434 & 0.7411 & -0.5889 & -4.2191 & -3.5330 & 0.9740 \\
\hline & 1st Difference & -3.7463 & -3.6210 & -2.9434 & 0.0072 & -3.7624 & -4.2268 & -3.5366 & 0.0303 \\
\hline
\end{tabular}

Null hypothesis: there is unit root; alternative hypothesis: there is no unit root

Source: The researcher based on data from 1980-2018 by using (Eviews9)

\section{Co-integration Johansen test}

To test the hypothesis of whether the variables are co-integrated and whether there is a longterm relationship between the variables, this paper used the Johansen co-integration test. The table (4) shows the results:

Tables 4 and 5 show that the trace statistics indicate two co-integrating equations at the (0.05) and (0.010) levels, which denotes a rejection of the hypothesis of no co-integration amongst the series at the (0.05) and (0.10) levels by (Mackinnon-Haug-Michelis, 1999). There is co-integration amongst the GDP, budget deficit, exchange rates, exports and operational expenditure. Hence, this test will be employed. The Max-Eigenvalue test indicates no co-integration at the (0.01) level. This denotes a rejection of the null hypothesis at the (0.05) level. Thereafter, to investigate the impact of the independent variables on the dependent variable and the model specification, this paper uses the Ordinary Least Square (OLS) regression.

\section{Ordinary Least Square (OLS)}

One of the most powerful methods of regression analysis is OLS. This method has certain attractive statistical properties which are employed to ensure the fulfilment of particular assumptions. These assumptions include the notion that all the independent variables are uncorrelated with the error term, and that the error term has a constant variance (that is no heteroscedasticity). No independent variable is a perfectly linear function of other explanatory variables, and the error term is normally distributed. The result of OLS estimation is as follows: 
The results show a weak significant positive impact of the budget deficit on economic growth $(\beta 1=0.09, p=0.0045)$, in which an increase of $1 \%$ in the budget deficit leads to an increase in the GDP by $0.09 \%$. This result is supported by(Nayab 2015).The exchange rate, in the table(6), has a significant and negative impact on economic growth $\left(\beta_{2}=-0.19, p=0.02\right)$ at the $5 \%$ level of significance.

The results also show that a $1 \%$ increase in the exchange rate leads to a decrease in the GDP by $0.19 \%$. This is supported by (Fatima et al., 2012). The last result shows that both exports and operational expenditure have a positive impact on the GDP by $0.13 \%$ and $0.11 \%$, respectively. The reason is that most of the Iraqi GDP comes from exporting oil, and most of the Iraqi government expenditure goes to the operating expenditure.

The value of $\mathrm{R}^{2}$ is $92 \%$, which validates the model. The Durbin Watson (DW) value is rather low at $1.07 \%$, which is not close to $2 \%$; therefore, there could be an autocorrelation problem, but at the next step, the diagnostic test for the model is to be performed to determine the long- and short-term relationships between the series in the model; this paper used the ARDL co-integration technique.

\section{ARDL Model}

To test the short-term dynamics and the long-term relationship of the considered variables in the model, this paper used(Granger, 1981)(Engle, Granger, Engle, \& Grangeri, 1987), and the ARDL co-integration procedure. This model of co-integration analysis is applicable in cases where variables of the same order are integrated [I (0) or I (1)] ${ }^{(1)}$ (Nkoro \& Uko, 2016)the means and variances are constant and not depending on time. However, most empirical researches have shown that the constancy of the means and variances are not satisfied in analyzing time series variables. In the event of resolving this problem most cointegration techniques are wrongly applied, estimated, and interpreted. One of these techniques is the Autoregressive Distributed Lag (ARDL. Hence, the ADF test results show that the variables used in this paper were [I (1) $]^{(2)}$. The ARDL model approach to co-integration testing is as follows:

$$
\Delta L G D P_{t}=\delta_{0 i}+\sum_{i=1}^{p} a_{1} \Delta L G D P_{t-1}+\sum_{i=1}^{q} a_{2} L B D_{t-i}+\sum_{i=1}^{q} a_{3} L E X_{t-i}+\sum_{i=1}^{q} a_{4} L E X C H_{t-i}+\sum_{i=1}^{q} a_{5} L O E_{t-i}+\lambda E C T_{t-1}+V_{i} \ldots \ldots .
$$

where

$\lambda=\left({ }^{1-} \sum_{i=1}^{p} \delta_{i}\right)$, is the speed of adjustment parameters with a negative sign.

$\mathrm{ECT}=\left(L G D P_{t-i}-\theta X_{t}\right)$, is the error correction term.

$\theta=\frac{\sum_{i=0}^{q} B_{i}}{a}$, are the long-term parameters.

$\alpha_{1^{\prime}} \alpha_{2^{\prime}} \alpha_{3^{\prime}} \alpha_{4^{\prime}} \alpha_{5}$ are the short-term dynamic coefficients of the model's adjustment to the long-term equilibrium.

Thereafter, to test whether there is co-integration between the series or not, the current study used the ARDL co-integration analysis. This estimation helps with the next investigation of the short- and long-term correlations between the variables in the model. For this purpose, usually the F-test is used to test the null

(1) Johansen \& Juselius (1990),(Pesaran, 1995) and Pesaran, Shinand Smith (2001) are used in determining the short- and long-term relationships between the series with different orders[i.e., series-A is I(1) and series-B is I(0)].

(2) I (1) mean the variables are stationary in the first difference. 
hypothesis of no co-integration among the variables. The main hypothesis of the Long Run Form and Bound Test are as follows:

$$
\begin{aligned}
& \mathrm{H}_{0}: \alpha_{1}=\alpha_{2}=\alpha_{3}=\alpha_{4}=\alpha_{5}=0 \text { (no co-integration) } \\
& \mathrm{H}_{\mathrm{a}}: \alpha_{1} \neq \alpha_{2} \neq \alpha_{3} \neq \alpha_{4} \neq \alpha_{5} \neq 0 \text { (co-integration) }
\end{aligned}
$$

If the value of the F-statistics is greater than I (1) bound, the null hypothesis of no co-integration is rejected. If it is below I (0) bound, the null hypothesis of no co-integration cannot be rejected. If the value of the F-statistic is between I (0) bound and I (1) bound, the test is inconclusive. If the test is inconclusive, an estimate of the short-term relationship should be made. The empirical co-integration test results are shown in Table (7):

Table 7 shows that the value of the F-statistics (6.09) is greater than the critical value in both EViews and Narayan table $5 \%$ and $10 \%$. Thereafter, we can reject the null hypothesis of no co-integration among the series and move to the next step, which are the short- and long-term estimations between the variables by using the ARDL model.

\section{Error Correction Model (ECM) and ARDL}

Through a simple linear equation, the

Table 7: Co-integration test: An ARDL approach for the bud-

\begin{tabular}{|c|c|c|c|c|}
\hline $\begin{array}{c}\text { Level of } \\
\text { significant }\end{array}$ & Critic & al values & F-statistic & Co-integration \\
\hline $\begin{array}{c}\text { dependent } \\
\text { variables GDP }\end{array}$ & $\begin{array}{l}\text { EViews } \\
(2005) \\
\end{array}$ & Narayan & \multirow{5}{*}{6.0966} & \multirow{5}{*}{$\begin{array}{l}\text { Indicate existing } \\
\text { co-integration } \\
\text { between economic } \\
\text { growth and } \\
\text { other independent } \\
\text { variables }\end{array}$} \\
\hline $10 \%$ & 2.453 .52 & 2.6963 .868 & & \\
\hline $5 \%$ & 2.864 .01 & 3.2764 .630 & & \\
\hline $2.5 \%$ & 3.254 .49 & & & \\
\hline $1 \%$ & 3.745 .06 & 4.5906 .368 & & \\
\hline
\end{tabular}
get deficit and economic growt ${ }^{*}$

Note:

In the regression model, there are four independent variables $(K=4)$, and the observations number is $35(\mathrm{~N}=39)$.

The critical value was the result of the software estimation (EViews 9). The critical values are taken from Nayaran (2005), table case III, unrestricted in intercept and no trend. ECM can be derived from the ARDL model.

The ARDL co-integration method tests whether there is an existence or absence of a long-term relationship between the budget deficit and economic growth. The associated ECM model takes a sufficient number of lags to capture the data generating process in general to a specific modelling framework. Once the longterm model in Model (4) to obtain the estimated residuals has been completed, the next step is to estimate the ECM model with the variables in the first differences, including the long-term relationships as error correction terms in the system. If there is a co-integration between the variables, Model (5) presents the long-term model, and Model (6) shows the short-term dynamics:

$$
\begin{aligned}
& \Delta L G D P_{t}=\delta_{0 i}+\sum_{i=1}^{p} a_{1} \Delta L G D P_{t-1}+\sum_{i=1}^{q} a_{2} L B D_{t-i}+\sum_{i=1}^{q} a_{3} L E X_{t-i}+\sum_{i=1}^{q} a_{4} L E X C H_{t-i}+\sum_{i=1}^{q} a_{5} L O E_{t-i}++V_{i} \ldots \\
& \Delta L G D P_{t}=\delta_{0 i}+\sum_{i=1}^{p} a_{1} \Delta L G D P_{t-1}+\sum_{i=1}^{q} a_{2} L B D_{t-i}+\sum_{i=1}^{q} a_{3} L E X_{t-i}+\sum_{i=1}^{q} a_{4} L E X C H_{t-i}+\sum_{i=1}^{q} a_{5} L O E_{t-i}+\lambda E C T_{t-1}+V_{i} \ldots . .
\end{aligned}
$$

Where $\lambda$ is the coefficient of the error correction term (hereafter ECT), it shows how quickly the variables converge to an equilibrium, and they should have a statistically significant coefficient with a negative sign. An appropriate lag selection is based on the criterion called the Akakie Information Criterion (AIC) ${ }^{(1)}$. The long-and short-term estimations are reported in Table 8.

The significance of an error correction term (ECT) shows the evidence of a long-term relationship between the variables. The lagged error correction term $\left(\mathrm{ECT}_{\mathrm{t}-1}\right)$ in the results is negative and significant at the $1 \%$ level. The coefficient of the ECT is (-0.52), which indicates a high rate of convergence to equilibrium.

(1) For more details, please refer to:

Appendix (1) presents a table of the top 20 ARDL models from the Akakie Information Criterion (AIC).

Appendix (2) shows the results of all the variables when they are dependent and independent in the model. 
Table 8 shows the results of the long- and short-term relationships among the variables in the model. All of the variables, including the lagged variables, are statistically significant at $1 \%, 5 \%$ and $10 \%$, except [(D (LOE) (-1)] and [LOE $(-2)]$, which are insignificant. The results show that there is a weak correlation between the current GDP and budget deficit, and a strong negative impact from the lagged value [ $\operatorname{LBD}(-1)]$ and [D (LBD (-1)] to the GDP in both the long and short term, respectively.

According to the findings, when the budget deficit increases by $1 \%$ in the previous year, it leads to a decline in the GDP by $0.16 \%$ in the long term. Also, in the short term, when the budget deficit increases in the previous year by $1 \%$, the GDP decreases by $0.11 \%$. This result is consistent with the OLS result, which was a weak impact from the budget deficit to the GDP, the study's hypothesis by Fatima et al.(2012), and the Neoclassical theory. In sum, this result showed that there is a low positive relationship between the budget deficit and the GDP, but that an accumulating budget deficit has a strong negative impact on the GDP.

Other variables including operational expenditure in all three lags has a significant negative impact on economic growth in the long term, which is a result of Iraqi fiscal policy that allocates the biggest amount of government expenditure to the operational expenditure.

The last result shows that the exchange rate has a negative impact on economic growth. Hence, Iraq is an importing country; the local production is not sufficient. Therefore, Iraqi should try to import goods and services from the countries in the broad, which means that the exchange rate is one of the most powerful variables that affects the Iraqi economy. On the other hand, $85 \%$ of the sources of the GDP are oil, which is exported abroad. In this situation, any changes to the exports and exchange rates directly affects the Iraqi GDP.

\section{Diagnostic Tests}

One of the most important techniques for testing the ARDL model to ensure that it does not have any regression problems is diagnostic testing. This test includes a serial correlation, heteroscedasticity, normality, function form and structural breaks.

The results show that the model is free of any autocorrelations, based on the probability value (0.10), which is more than (0.05), thus the null hypothesis of no autocorrelation cannot be rejected. The findings from Breusch-Pagan
Table 8: Estimated ARDL models, long-term coefficients, short-term error correction model and the ARDL $(2,2,2,0,3)$

\begin{tabular}{cccc}
\hline \multicolumn{1}{c}{ ARDL Long Run Form and Bounds Test (ECM) } \\
\hline Variables & Coefficient & T-test & P. value \\
\hline Constant & 14.9807 & 6.1595 & 0.0000 \\
\hline D (LGDP (-1)) & 0.6499 & 4.6957 & 0.0002 \\
\hline D(LEXCH) & -0.6672 & -12.9254 & 0.0000 \\
\hline D (LEXCH (-1)) & 0.2651 & 3.7549 & 0.0016 \\
\hline D(LBD) & 0.0512 & 2.7986 & 0.0123 \\
\hline D (LBD (-1)) & -0.1621 & -6.3743 & 0.0000 \\
\hline D(LOE) & -0.3175 & -5.7752 & 0.0000 \\
\hline D (LOE (-1)) & -0.0577 & -1.2142 & 0.2413 \\
\hline D (LOE (-2)) & -0.1555 & -3.0287 & 0.0076 \\
\hline \multicolumn{4}{c}{ Short-term estimation } \\
\hline Constant & 14.9807 & 4.1757 & 0.0006 \\
\hline LGDP $(-1)$ & 1.12678 & 4.9845 & 0.0001 \\
\hline LGDP $(-2)$ & -0.6499 & -3.4420 & 0.0031 \\
\hline LBD & 0.0512 & 1.8602 & 0.0802 \\
\hline LBD (-1) & -0.1159 & -3.6372 & 0.0020 \\
\hline LBD $(-2)$ & 0.1621 & 3.9290 & 0.0011 \\
\hline LEXCH & -0.6672 & -5.4833 & 0.0000 \\
\hline LEXCH $(-1)$ & 0.6968 & 5.6804 & 0.0000 \\
\hline LEXCH (-2) & -0.2651 & -2.2784 & 0.0359 \\
\hline LEX & -0.2072 & -2.0668 & 0.0543 \\
\hline LOE & -0.3175 & -2.7139 & 0.0147 \\
\hline LOE (-1) & 0.3055 & 2.6059 & 0.0185 \\
\hline LOE (-2) & -0.0977 & -1.1340 & 0.2725 \\
\hline LOE (-3) & 0.1555 & 2.3694 & 0.0299 \\
\hline Constant & 14.980 & 4.1757 & 0.0006 \\
\hline ECT (-1) & -0.5231 & -6.8076 & 0.0000 \\
\hline & & &
\end{tabular}

\section{Table 9: Diagnostic checking of the ARDL model}

\begin{tabular}{cccc}
\hline \multicolumn{5}{c}{ Diagnostic Test } \\
\hline Test statistics & Test statistics & F version & Decision \\
\hline Serial correlation & Breusch-Godfrey & $\mathrm{F}(11,6)=(2.887)[0.1023]$ & Accept \\
\hline Heteroscedasticity & Breusch-Pagan-Gogfrey & $\mathrm{F}(13,17)=(0.524)[0.8786]$ & Accept \\
\hline Function form & Ramsey RESET test & $\mathrm{F}(1,16)=(0.006)[0.980]$ & Accept \\
\hline Normality & Jargue-Bera & $\mathrm{JB}=(1.6775)[0.4322]$ & Accept \\
\hline Stability test & CUSUM test & Structural break stable & Stable \\
\cline { 2 - 4 } & CUSUMQ test & Structural break stable & Stable \\
\hline Test statistics & & & \\
\hline R-squared & 0.98 & F- statistic & $76.79[0.00]$ \\
\hline Adjusted R-squared & 0.97 & S.E of regression & 0.092 \\
\hline Number of observations & 35 & D.W- statistic & 2.7 \\
\hline
\end{tabular}


demonstrated that the model does not have a heteroscedasticity problem, and that the error is homoscedasticity. The other evidence from the ARDL model is the result of Standard Error (S.E) which is a minimum and small value (0.092). Finally, in terms of $R^{2}$ and adjusted $R^{2}$, these results show the good fit of the model.

The last test for checking whether the model is accurate is the stability test. The results from this test show how the study is useful as a decision maker. The results of the stability tests are presented as follows:
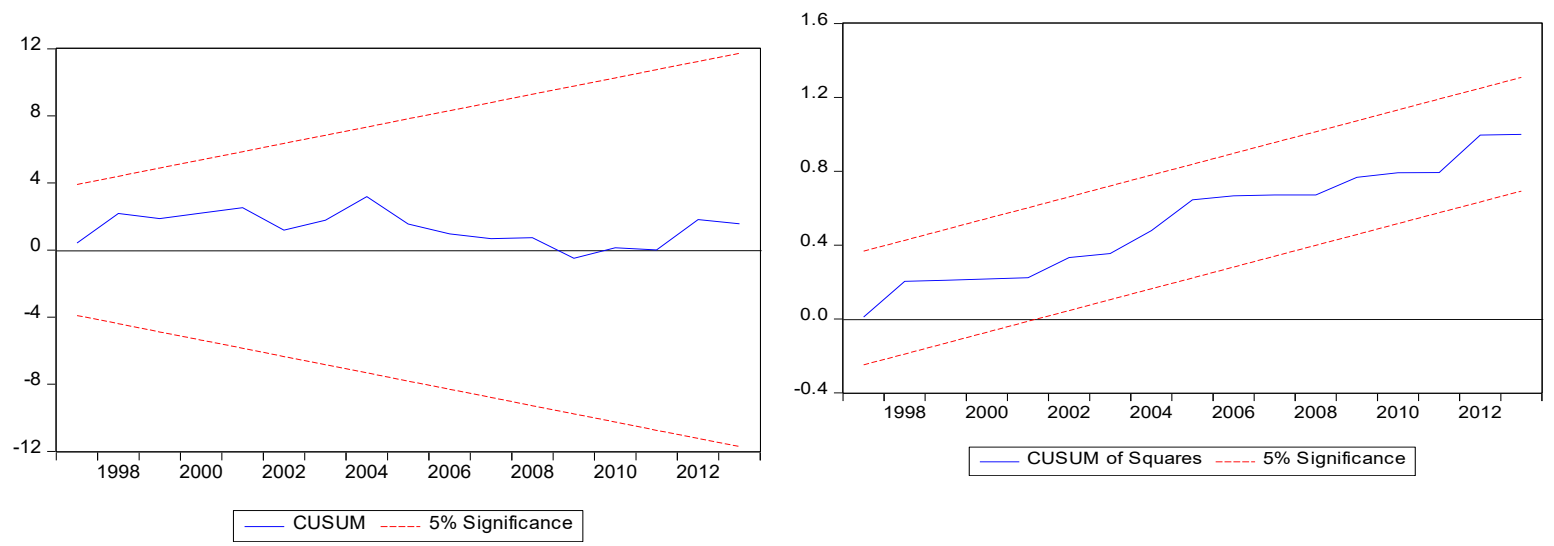

Figure 5: Plot of the cumulative sum of recursive residuals

From the plots of the CUSUM and CUSUMQ, they show that no evidence of any significant structural instability has been observed.

\section{Conclusion}

A major problem in the Iraqi economy is the dependence on one source of revenue that is the oil exports. In 2018, 84\% of the government's budgeted revenues are oil revenues, and $16 \%$ are non-oil revenues, mainly from income, corporate and other taxes. On the other hand, operational expenditure represents around $76 \%$ of the government's budgeted expenditure; however, the investment expenditure represents only around $24 \%$. This distribution has created the budget deficit, which is $12 \%$ (the Ministry of Finance 2018). There are reasons for this imbalanced budget: the number of government employees is high, the existence of corruption and the mismanagement.

This paper has endeavoured to find out whether there is a relationship between the budget deficit and economic growth in Iraq. It applied the ARDL model to investigate the long- and short-term relationships among the variables. The regression is a time serious analysis, which includes the annual data set from 1980 to 2018. The results show that there is a positive relationship between the budget deficit and economic growth in the short term. As such, an accumulating deficit leads to a negative impact on economic growth in the long term.

For the researcher, their role was to apply the model to different periods of time to validate the results of this research in Iraq or other Western Asia countries. Other variables could be used, such as a budget surplus as a major variable in the model to check the impact of the budget surplus on economic growth.

The main recommendations from this study are that the Iraqi government should diversify its source of revenues because oil revenues are not stable nor sufficient to cover the budget deficit. Hence, the government needs a plan to increase its non-oil revenues by diversifying and increasing local production, expanding the private sector and reforming fiscal policy to increase its investment expenditure. 


\section{References}

Argimon, Isabel; Jose M. Gonzalez-Paramo and Jose M. Roldan. (1997). “Evidence of public spending crowding-out from a panel of OECD countries", Applied Economics, 29, No. 8, pp. 1001-1010.

- $\quad$ Arjomand, Mansoor; Karim Emami and Farshid Salimi. (2016). “Growth and productivity: The role of budget deficit in the MENA selected countries", Procedia Economics and Finance, 36, pp. 345-352.

- $\quad$ Awe, A. A., and A. K. Funlayo. "The short and long-run implications of budget deficit on economic growth in Nigeria (1980-2011)." Canadian Social Science 10, no. 5 (2014): 201.

- $\quad$ Al-Khedair, Saleh I. (1997). "The impact of the budget deficit on key macroeconomic variables in the major industrial countries", pp. 3243-3243.

- $\quad$ Alesina, Alberto; Nouriel Roubini and Gerald D. Cohen. (1997). Political cycles and the macroeconomy", MIT Press.

- Antwi, Samuel and Ebenezer Atta Mills. (2013). “Consequential effects of budget deficit on economic growth: Empirical evidence from Ghana", International Journal of Economics and Finance, 5 , No. 3.

- $\quad$ Argimon, Isabel; Jose M. Gonzalez-Paramo and Jose M. Roldan. (1997). “Evidence of public spending crowding-out from a panel of OECD countries", Applied Economics, 29, No. 8, pp. 1001-1010. Aschauer, David Alan. (1989). “Does public capital crowd out private capital?" Journal of Monetary Economics, 24, No. 2, pp. 171-188.

- Bahmani-Oskooee, Mohsen. (1999). "Do federal budget deficits crowd out or crowd in private investment?" Journal of Policy Modeling, 21, No. 5, pp. 633-640.

- Barişik, Salih and Abdullah Baris. (2017). "Impact of governance on budget deficit in developing countries", Theoretical \& Applied Economics, 24, No. 2.

- Barro, Robert J. (1989) "The ricardian approach to budget deficits", Journal of Economic Perspectives, 3, No. 2, pp. 37-54.

- Bemheim, B. Douglas. (1989). "A neoclassical perspective on budget deficits", Journal of Economic Perspectives, 3, pp. 55-72.

- $\quad$ Buiter, Willem H. (1977). "Crowding-out and the effectiveness of fiscal policy”, Journal of Public Economics, 7, No. 3, pp. 309-328.

- Coddington, Alan. (1976). "Keynesian economics: The search for first principles", Journal of Economic Literature, 14, No. 4 , pp. 1258-1273.

- $\quad$ Cohen, Darrel and Olivier Garnier. (1991). The impact of forecasts of budget deficits on interest rates in the United States and other G-7 countries, Federal Reserve Board.

- Gujarati, Damodar N. Basic econometrics. (BookFi).pdf, 2004.

- Dao, Binh. (2013). The relationship between budget deficit and economic growth in Vietnam. Available at SSRN 2514134 (2013).

- Dickey, David A. and Wayne A. Fuller. (1981). "Likelihood ratio statistics for autoregressive time series with a unit root", Econometrica: Journal of the Econometric Society, pp. 1057-1072.

- Edame, Greg Ekpung and Okoiarikpo Benjamin Okoi. (2015). “Fiscal deficits and economic growth in Nigeria: A chow test approach", International Journal of Economics and Financial Issues, 5, No. 3, pp. 748-752.

- $\quad$ Engle, Robert F. and Clive W. J. Granger. (1987). “Co-integration and error correction: representation, estimation and testing", Econometrica: Journal of the Econometric Society", pp. 251-276. 
Eisner, Robert. (1989). "Budget deficits: rhetoric and reality", Journal of Economic perspectives, 3, No. 2, pp. 73-93.

- $\quad$ Elmendorf, Douglas W. (1993). Actual budget deficit expectations and interest rates. No. 1639. Harvard-Institute of Economic Research.

- Elmendorf, Douglas W. (1996). The effects of deficit-reduction laws on real interest rates. Division of Research \& Statistics and Monetary Affairs, Federal Reserve Board.

- Elmendorf, Douglas W. and N. Gregory Mankiw. (1999). “Government debt", In: Handbook of macroeconomics, 1, pp. 1615-1669.

- Evans, Paul. (1987). "Interest rates and expected future budget deficits in the United States", Journal of Political Economy, 95, No. 1, pp. 34-58.

- Fatima, Goher; Mehboob Ahmed and Wali Rehman. (2012). “Consequential effects of budget deficit on economic growth of Pakistan", International Journal of Business and Social Science, 3, No. 7.

- Martin Feldstein, 1986. "Budget Deficits, Tax Rules, and real Interest Rates," NBER Working Papers 1970, National Bureau of Economic Research, Inc.

- Ghali, Khalifa H. )1997). "Government spending and economic growth in Saudi Arabia." Journal of Economic Development, 22, No. 2, pp. 165-172.

- Granger, Clive W. J. (1981). "Some properties of time series data and their use in econometric model specification", Journal of Econometrics, 16, No. 1, pp. 121-130.

- Guess, George and Kenneth Koford. (1986). “Inflation, recession and the federal budget deficit or, blaming economic problems on a statistical mirage", Policy Sciences, 17, No. $4(1984,1986)$ pp. 385-402.

- Gülcan, Yaprak and Mustafa Erhan Bilman. (2005). The effects of budget deficit reduction on exchange rate: evidence from Turkey, Dokuz Eylül University DP Series 5, No. 07.

- Herrera, S. (2007). Public expenditure and growth. The World Bank.

- Huynh, N. D. (2007). Budget deficit and economic growth in developing countries: The case of Vietnam. Kansai institute for social and economic research (KISER).

- Jalles, A. A. and J. T. (2011). Ujberdie Messunyder optischen Konstantensehr dliinner Metallsohichten. Von E. Forsterling. pp. 745-751.

- Johansen, Søren, and Katarina Juselius. "Maximum likelihood estimation and inference on cointegration — with applications to the demand for money." Oxford Bulletin of Economics and statistics 52, no. 2 (1990): 169-210.

- Landau, Daniel. “Government expenditure and economic growth: a cross-country study." Southern Economic Journal (1983): 783-792.

- Lim, G. (n.d.). [William_E._Griffiths,_R._Carter_Hill,_Mark_Andrew (BookSee.org).

- Modigliani, Franco. "The Monetarist Controversy, or, Should We Forsake Stabilization Policies?" In Essential Readings in Economics, pp. 383-408. Palgrave, London, 1995.

- Nayab, Humera. "The relationship between budget deficit and economic growth of Pakistan." Journal of Economics and Sustainable Development 6, no. 11 (2015): 85-90.

- Nkoro, Emeka, and Aham Kelvin Uko. "Autoregressive Distributed Lag (ARDL) cointegration technique: application and interpretation." Journal of Statistical and Econometric Methods 5, no. 4 (2016): 63-91. 
- Pesaran, M. Hashem, Yongcheol Shin, and Richard J. Smith. "Bounds testing approaches to the analysis of level relationships." Journal of applied econometrics 16, no. 3 (2001): 289-326.

- Roberto Rocha "Review of Financial Market of Uzbekistan." research gate, (1995).

- $\quad$ Republics of Iraq. budget, Ministry of Finance and Ministry of planning,2004.

- Salm, S. abdulhsain. (2012). Budget Deficiency and Its Treatment Prospects and Policies with Reference to Iraq (2003-2012). Scientific Journal of Economics and Management, 68.

- Shojai, S. Budget Deficits and Debt: A Global Perspective, xiii, (1999), 194.

- Saleh, Ali Salman, and Charles Harvie. "The budget deficit and economic performance: A survey." The Singapore Economic Review 50, no. 02 (2005): 211-243.

- Sargent, Thomas J., and Neil Wallace. "Some unpleasant monetarist arithmetic." Federal reserve bank of Minneapolis quarterly review 5, no. 3 (1981): 1-17.

- $\quad$ Shaviro, Daniel. Do deficits matter? University of Chicago Press, 1997.

- Tanzi, Vito. "Fiscal deficits and interest rates in the United States: an empirical analysis, 1960-84." Staff Papers 32, no. 4 (1985): 551-576.

- Tanzi, Vito, and Ludger Schuknecht. "Reconsidering the fiscal role of government: the international perspective." The American Economic Review 87, no. 2 (1997): 164-168.

- Tobin, James. "The monetary-fiscal mix: long-run implications." The American Economic Review 76, no. 2 (1986): 213-218.

- $\quad$ Tobin, J." The American Economic Review76 (2), (1986): 213-218.

- Wachtel, Paul, and John Young. "Deficit announcements and interest rates." The American Economic Review 77, no. 5 (1987): 1007-1012.

- $\quad$ Worldwide look at reserves and production, Oil \& Gas Journal, 1 January 2015.

- Van, Vien Bui, and Tatchalerm Sudhipongpracha. "Exploring government budget deficit and economic growth: Evidence from Vietnam's economic miracle." Asian Affairs: An American Review 42, no. 3 (2015): 127-148.

- Yellen, Janet L. "Symposium on the budget deficit." Journal of Economic Perspectives 3, no. 2 (1989): 17-21.

- Nurudeen, Abu, and Abdullahi Usman. “Government expenditure and economic growth in Nigeria, 1970-2008: A disaggregated analysis." Business and economics journal (2010).

\section{Appendix 1}

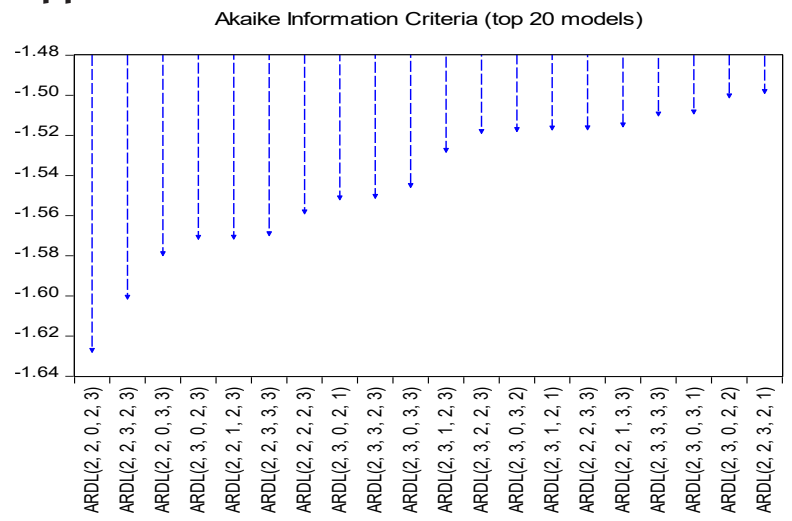

\section{Appendix 2}

Results of all the variables in the Error Correction Models

\begin{tabular}{|c|c|c|c|}
\hline $\begin{array}{c}\text { Dependent } \\
\text { Variable }\end{array}$ & F-statistic & \multicolumn{2}{|c|}{ Estimation Co-integration } \\
\hline LGDP & $\begin{array}{l}F=6.0966 \\
t=-3.0577\end{array}$ & ECM & YES \\
\hline LEXCH & $\begin{array}{c}F-16.750 \\
t=-2.2320\end{array}$ & ECM & YES \\
\hline LEX & $\begin{array}{l}\mathrm{F}=20.1131 \\
\mathrm{t}=-7.8298\end{array}$ & ECM & YES \\
\hline LBD & $\begin{array}{l}\mathrm{F}=8.1994 \\
\mathrm{t}=-5.51605\end{array}$ & ECM & YES \\
\hline LOE & $\begin{array}{l}\mathrm{F}=16.6197 \\
\mathrm{t}=-2.6644\end{array}$ & ECM & YES \\
\hline
\end{tabular}

